Chinese Journal of Organic Chemistry

\title{
小盘木中多样性二萜类化合物
}

\author{
韩光辉 $a, b$ 任宇豪 $b$ 范耀月 $b$ 纪开龙 ${ }^{b}$ \\ 周 涁 $b$ 曹卫国*, 岳建民*,b \\ $\left({ }^{a}\right.$ 上海大学理学院化学系 上海 200444) \\ $\left({ }^{b}\right.$ 中国科学院上海药物研究所 新药研究国家重点实验室 上海 201203)
}

\begin{abstract}
摘要 从小盘木植物中分离鉴定了四个新二萜类化合物 1 4, 分别属于 dolabrane 烷型、玫瑰烷型、半日花烷型以及烟 草烷型. 综合利用各种光谱数据阐明了四个二萜类化合物的相对立体结构, 并通过圆二色谱(ECD)数据确定了它们的 绝对构型.

关键词 小盘木; 小盘木属; 二萜化合物; 小盘木素 $\mathrm{A} \sim \mathrm{D}$; 结构解析; 圆二色谱 $(\mathrm{ECD})$ 分析
\end{abstract}

\section{Diverse Diterpenoids from Microdesmis casearifolia}

\author{
Han, Guanghui ${ }^{a, b} \quad{\text { Ren, } \text { Yuhao }^{b} \quad \text { Fan, Yaoyue }^{b} \quad \text { Ji, Kailong }}^{b}$ \\ Zhou, Bin $^{b} \quad$ Cao, Weiguo*,a Yue, Jianmin ${ }^{*, b}$ \\ $\left({ }^{a}\right.$ Department of Chemistry, College of Science, Shanghai University, Shanghai 200444) \\ $\left({ }^{b}\right.$ State Key Laboratory of Drug Research, Shanghai Institute of Materia Medica, \\ Chinese Academy of Sciences, Shanghai 201203)
}

\begin{abstract}
Four new diterpenoids, casearoids $A \sim D(\mathbf{1} \sim \mathbf{4})$, including dolabrane, orosane, labdane, and cembrane, were isolated and characterized from Microdesmis casearifolia. Their structures were elucidated by extensive spectroscopic data analysis. The absolute configurations of these diterpenoids were established by analysis of the electronic circular dichroism (ECD) data.

Keywords Microdesmis casearifolia; Microdesmis genus; diterpenoid; casearoids A $\sim$ D; spectroscopic analysis; electronic circular dichroism (ECD) analysis
\end{abstract}

\section{Introduction}

The Microdesmis genus (Pandaceae family) consists of 10 species that mainly distributed in African, and tropical and subtropical Asian countries. ${ }^{[1]}$ Only one specie, $\mathrm{Mi}$ crodesmis casearifolia grows in China, which has been applied as folk medicine in China for the treatment of hemostasis swelling, ringworm, wart, and teeth pain. Previous chemical investigations on Microdesmis plants led to the isolation of diverse compound classes, including spermidines, ${ }^{[2-5]}$ quinoline alkaloids ${ }^{[6]}$ and terpenoids. ${ }^{[7]}$ Terpenoids, widely distributed in nature and exhibiting various biological activities, are important sources of lead compounds in drug discovery. In the continuation of our ongoing project for the discovery of novel diterpenoids from medicinal plants, ${ }^{[8-13]}$ an initial chemical study on the twigs and leaves of $M$. casearifolia was carried out for the first time, which afforded four new diterpenoids, casearoids $A \sim D(\mathbf{1} \sim \mathbf{4})$, representing four different types.
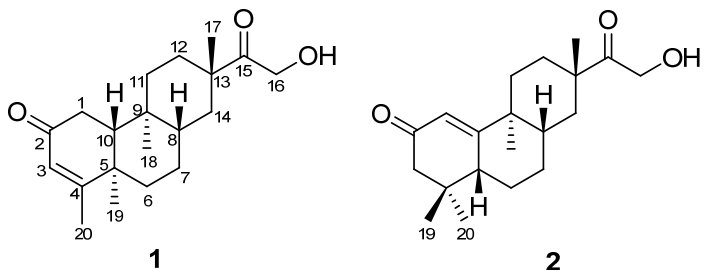

\footnotetext{
* Corresponding authors. E-mail: wgcao@staff.shu.edu.cn; jmyue@simm.ac.cn Received May 22, 2020; revised June 16, 2020; published online June 30, 2020. Project supported by the National Natural Science Foundation of China (Nos. 21532007, 21772213), the Drug Innovation Major Project of China (No. 2018ZX09711001-001-005), the Biological Resources Program of Chinese Academy of Sciences (No. KFJ-BRP-008) and the Youth Innovation Promotion Association, Chinese Academy of Sciences.

国家自然科学基金(Nos. 21532007，21772213)、国家重大新药创制专项(No. 2018ZX09711001-001-005)、中国科学院战略生物资源计划(No. KFJ-BRP-008)及中国科学院青年创新促进会资助项目。
} 


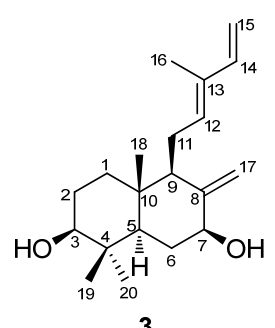

3

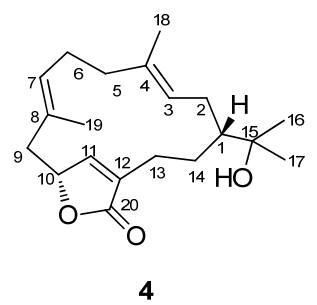

Their structures were completely elucidated on the basis of comprehensive analysis of the spectroscopic data, as well as time dependent density functional theory (TDDFT)based electronic circular dichroism (ECD) calculation.

\section{Results and discussion}

Casearoids A (1) had a molecular formula of $\mathrm{C}_{20} \mathrm{H}_{30} \mathrm{O}_{3}$ as established by the protonated HRESIMS ion peak at $\mathrm{m} / \mathrm{z}$ $319.2263[\mathrm{M}+\mathrm{H}]^{+}$(calcd 319.2268) and ${ }^{13} \mathrm{C}$ NMR data, suggestive of six indices of hydrogen deficiency (IHD). The IR spectrum showed the presence of hydroxy (3451 $\left.\mathrm{cm}^{-1}\right)$, carbonyl $\left(1713 \mathrm{~cm}^{-1}\right)$ and vinyl $\left(1663 \mathrm{~cm}^{-1}\right)$ functional groups. Its ${ }^{13} \mathrm{C}$ NMR data combined with distortionless enhancement by polarization transfer (DEPT) experiments (Table 1) revealed the presence of four methyls, seven methylenes (one oxygenated), two methines, three $\mathrm{sp}^{3}$ quaternary carbons, two carbonyl carbons $\left(\delta_{\mathrm{C}} 200.2\right.$ and 215.3) and one trisubstituted double bonds. The abovementioned functional groups accounted for three out of the six IHDs, which demanded compound $\mathbf{1}$ to possess three rings in the structure.

The planar structure of $\mathbf{1}$ was constructed by the interpretation of the 2D NMR spectra (Figure 1A). Briefly, the ${ }^{1} \mathrm{H}-{ }^{1} \mathrm{H}$ COSY correlations of $\mathbf{1}$ indicated three spin systems as sketched in bold lines, which were then connected with the quaternary carbons and oxygen atoms by the HMBC analysis (Figure 1A) to furnish the diterpenoid framework.

Table $1{ }^{1} \mathrm{H}$ NMR (600 MHz) and ${ }^{13} \mathrm{C}$ NMR (125 MHz) data for compounds $\mathbf{1} \sim \mathbf{4}$

\begin{tabular}{|c|c|c|c|c|c|c|c|c|}
\hline & \multicolumn{2}{|l|}{$\mathbf{1}^{a}$} & \multicolumn{2}{|l|}{$\mathbf{2}^{a}$} & \multirow{2}{*}{$\frac{\mathbf{3}^{a}}{\delta_{\mathrm{H}}(J \text { in } \mathrm{Hz})}$} & \multicolumn{3}{|c|}{$4^{a}$} \\
\hline & $\delta_{\mathrm{H}}(J$ in $\mathrm{Hz})$ & $\delta_{\mathrm{C}}$ & $\delta_{\mathrm{H}}(J$ in $\mathrm{Hz})$ & $\delta_{\mathrm{C}}$ & & $\delta_{\mathrm{C}}$ & $\delta_{\mathrm{H}}(J$ in $\mathrm{Hz})$ & $\delta_{\mathrm{C}}$ \\
\hline \multirow[t]{2}{*}{1} & $\alpha 2.34, \mathrm{dd}(17.5,14.0)$ & 34.6 & $5.99, \mathrm{~d}(2.7)$ & 123.1 & $\alpha 1.21, \mathrm{dt}(12.9,3.8)$ & 37.0 & $1.48 \sim 1.52, \mathrm{~m}$ & 47.6 \\
\hline & $\beta 2.44, \mathrm{dd}(17.5,3.7)$ & & & & $\beta 1.80, \operatorname{td}(12.9,3.6)$ & & & \\
\hline \multirow[t]{2}{*}{2} & & 200.2 & & 200.3 & $\alpha 1.71 \sim 1.74, \mathrm{~m}$ & 28.1 & $\alpha 2.15 \sim 2.19, \mathrm{~m}$ & 29.5 \\
\hline & & & & & $\beta 1.60 \sim 1.63, \mathrm{~m}$ & & $\beta 1.79 \sim 1.85, \mathrm{~m}$ & \\
\hline \multirow[t]{2}{*}{3} & $5.71, \mathrm{~s}$ & 125.7 & $\alpha 2.17, \mathrm{~d}(1.5)$ & 53.5 & $3.99, \mathrm{dd}(11.7,4.3)$ & 78.8 & $5.06 \sim 5.09, \mathrm{~m}$ & 124.9 \\
\hline & & & $\beta 2.33, \mathrm{~d}(1.5)$ & & & & & \\
\hline 4 & & 172.1 & & 36.9 & & 39.1 & & 134.9 \\
\hline 5 & & 40.3 & $\begin{array}{l}2.54 \text {, ddd }(13.8,5.0, \\
2.8)\end{array}$ & 44.7 & 1.16 , dd $(12.9,2.6)$ & 52.3 & $2.10 \sim 2.13, \mathrm{~m}$ & 39.3 \\
\hline \multirow[t]{2}{*}{6} & $\alpha 1.87 \sim 1.90, \mathrm{~m}$ & 36.2 & $\alpha 1.86 \sim 1.89, \mathrm{~m}$ & 17.8 & $\alpha 2.11$, ddd $(12.1,5.6,2.6)$ & 33.4 & $2.15 \sim 2.17, \mathrm{~m}$ & 25.0 \\
\hline & $\beta 1.46 \sim 1.50, \mathrm{~m}$ & & $\beta 1.39 \sim 1.45, \mathrm{~m}$ & & $\beta 1.31 \sim 1.38, \mathrm{~m}$ & & & \\
\hline \multirow[t]{2}{*}{7} & $\alpha 1.50 \sim 1.52, \mathrm{~m}$ & 25.4 & $\alpha 1.35 \sim 1.38, \mathrm{~m}$ & 24.9 & 3.99 , dd $(10.8,5.6)$ & 73.8 & $5.06 \sim 5.09, \mathrm{~m}$ & 130.6 \\
\hline & $\beta 1.30 \sim 1.33, \mathrm{~m}$ & & $\beta 1.73 \sim 1.76, \mathrm{~m}$ & & & & & \\
\hline 8 & $1.35 \sim 1.39, \mathrm{~m}$ & 41.3 & $1.76 \sim 1.79, \mathrm{~m}$ & 30.5 & & 152.0 & & 128.4 \\
\hline \multirow[t]{2}{*}{9} & & 36.8 & & 38.4 & $1.63 \sim 1.67, \mathrm{~m}$ & 55.0 & $\alpha 2.44, \mathrm{dd}(13.5,7.5)$ & 42.2 \\
\hline & & & & & & & $\beta 2.48, \mathrm{dd}(13.5,3.9)$ & \\
\hline 10 & $1.74, \mathrm{dd}(14.0,3.7)$ & 52.9 & & 174.1 & & 39.1 & $5.00 \sim 5.03, \mathrm{~m}$ & 80.0 \\
\hline \multirow[t]{2}{*}{11} & $\alpha 1.60, \mathrm{t}(13.1)$ & 33.8 & $\alpha 1.79 \sim 1.83, \mathrm{~m}$ & 33.4 & $\alpha 2.36, \operatorname{ddd}(15.5,6.8,3.5)$ & 23.2 & $7.17, \mathrm{~d}(1.8)$ & 147.8 \\
\hline & $\beta 1.12, \operatorname{td}(14.0,4.8)$ & & $\beta 1.49 \sim 1.52, \mathrm{~m}$ & & $\begin{array}{l}\beta 2.24, \text { ddd }(15.5,11.1, \\
6.8)\end{array}$ & & & \\
\hline \multirow[t]{2}{*}{12} & $\alpha 1.84, \operatorname{td}(14.0,4.8)$ & 27.9 & $\alpha 1.83 \sim 1.85, \mathrm{~m}$ & 28.9 & $5.37, \mathrm{t}(6.6)$ & 133.0 & & 134.9 \\
\hline & $\beta 1.43$, ddt $(11.8,4.8,2.5)$ & & $\beta 1.54 \sim 1.56, \mathrm{~m}$ & & & & & \\
\hline 13 & & 45.6 & & 45.4 & & 134.0 & $2.42, \operatorname{td}(4.9,2.1)$ & 23.6 \\
\hline \multirow[t]{2}{*}{14} & $\alpha 1.58 \sim 1.63, \mathrm{~m}$ & 35.2 & $\alpha 1.49 \sim 1.52, \mathrm{~m}$ & 35.8 & $6.31, \mathrm{dd}(17.4,10.7)$ & 141.6 & $\alpha 1.83 \sim 1.89, \mathrm{~m}$ & 26.6 \\
\hline & $\beta 1.23 \sim 1.25, \mathrm{~m}$ & & $\beta 1.42 \sim 1.44, \mathrm{~m}$ & & & & $\beta 1.54 \sim 1.58, \mathrm{~m}$ & \\
\hline \multirow[t]{2}{*}{15} & & 215.3 & & 215.1 & $a 5.06, \mathrm{~d}(17.4)$ & 110.4 & & 74.2 \\
\hline & & & & & $b 4.89, \mathrm{~d}(10.7)$ & & & \\
\hline 16 & $4.39, \mathrm{~s}$ & 64.0 & $4.41, \mathrm{~s}$ & 64.1 & 1.75, br s & 12.0 & $1.25, \mathrm{~s}$ & 27.6 \\
\hline \multirow[t]{2}{*}{17} & $1.21, \mathrm{~s}$ & 20.7 & $1.19, \mathrm{~s}$ & 19.7 & $a 5.19$, br s & 104.7 & $1.23, \mathrm{~s}$ & 28.1 \\
\hline & & & & & $b 4.66$, br s & & & \\
\hline 18 & 1.89, br s & 19.0 & $1.03, \mathrm{~s}$ & 19.0 & $0.80, \mathrm{~s}$ & 15.6 & $1.60, \mathrm{~s}$ & 15.4 \\
\hline 19 & $1.13, \mathrm{~s}$ & 19.2 & $1.09, \mathrm{~s}$ & 29.0 & $1.03, \mathrm{~s}$ & 28.5 & $1.64, \mathrm{~s}$ & 18.2 \\
\hline 20 & $0.85, \mathrm{~s}$ & 12.3 & $0.83, \mathrm{~s}$ & 20.1 & $0.73, \mathrm{~s}$ & 14.6 & & 174.4 \\
\hline
\end{tabular}

${ }^{a}$ Measured in $\mathrm{CDCl}_{3}$. 
Combining with the ${ }^{1} \mathrm{H}-{ }^{1} \mathrm{H}$ COSY correlations of $\mathrm{H}_{2}-1$ / $\mathrm{H}-10$, the HMBC correlations of $\mathrm{H}-3 / \mathrm{C}-1$ and $\mathrm{C}-2 ; \mathrm{H}_{3}-19$ / $\mathrm{C}-4, \mathrm{C}-5, \mathrm{C}-6$ and $\mathrm{C}-10$; and $\mathrm{H}_{3}-20 / \mathrm{C}-3, \mathrm{C}-4$, and C-5 established the A-ring incorporating an $\alpha, \beta$-unsatu- rated ketone and bearing two methyls at C-4 and C-5. The B and $\mathrm{C}$ rings with two methyl groups at $\mathrm{C}-9$ and $\mathrm{C}-13$ were delineated by the ${ }^{1} \mathrm{H}-{ }^{1} \mathrm{H}$ COSY correlations of $\mathrm{H}_{2}-6 / \mathrm{H}_{2}-7 /$ $\mathrm{H}-8 / \mathrm{H}_{2}-14$ and $\mathrm{H}_{2}-11 / \mathrm{H}_{2}-12$, together with the key HMBC correlations of $\mathrm{H}_{2}-11 / \mathrm{C}-8, \mathrm{C}-10$, and $\mathrm{C}-13 ; \mathrm{H}_{3}-17 / \mathrm{C}-12$, C-13, C-14 and C-15; $\mathrm{H}_{3}-18 / \mathrm{C}-8$, C-9, C-10, and C-11; and $\mathrm{H}_{3}-19 / \mathrm{C}-4, \mathrm{C}-5$, and C-6. Additionally, a hydroxyacetyl group was attached at $\mathrm{C}-13$ by the key $\mathrm{HMBC}$ correlations of $\mathrm{H}_{2}-16 / \mathrm{C}-13$ and $\mathrm{C}-15$, and $\mathrm{H}_{3}-17 / \mathrm{C}-15$. The 2D structure of compound $\mathbf{1}$ was thus constructed as shown with a dolabrane framework, which is similar to that of ent$5 \alpha, 2,15$-dioxodolabr-3-ene-3,16-di- ol. ${ }^{[8,14]}$

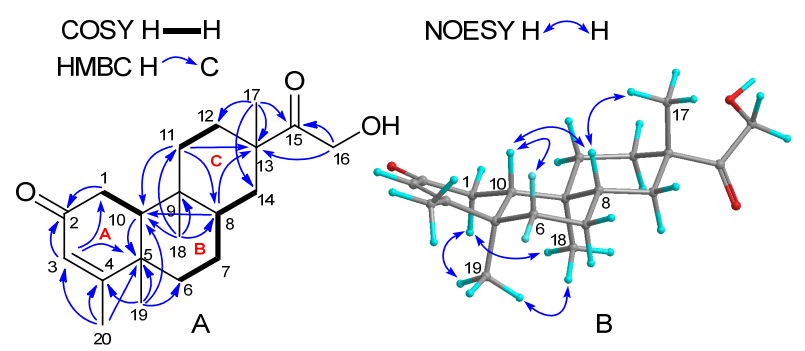

Figure 1 Key 2D NMR correlations of compound 1

The relative configuration of $\mathbf{1}$ was determined by the NOESY analysis (Figure 1B). The NOESY cross-peaks of $\mathrm{H}_{3}-18$ with $\mathrm{H}-1 \alpha$ and $\mathrm{H}_{3}-19$ indicated that these protons were in the same side of the molecule, and were arbitrarily assigned in a $\alpha$-orientation. Accordingly, H- $6 \beta, \mathrm{H}-8, \mathrm{H}-10$, and Me-17 were assigned as $\beta$-orientation on the basis of the NOESY correlations of $\mathrm{H}-10 / \mathrm{H}-6 \beta$ and $\mathrm{H}-8$, as well as $\mathrm{H}_{3}-17 / \mathrm{H}-8$. The absolute configuration of 1 was determined as depicted by comparing the experimental ECD spectrum of 1 with the calculated ECD curves. As shown in Figure 2, the calculated ECD spectrum was roughly matched that of the experimental one, which established the absolute configuration of $\mathbf{1}$ as $5 R, 8 S, 9 S, 10 R, 13 S$.

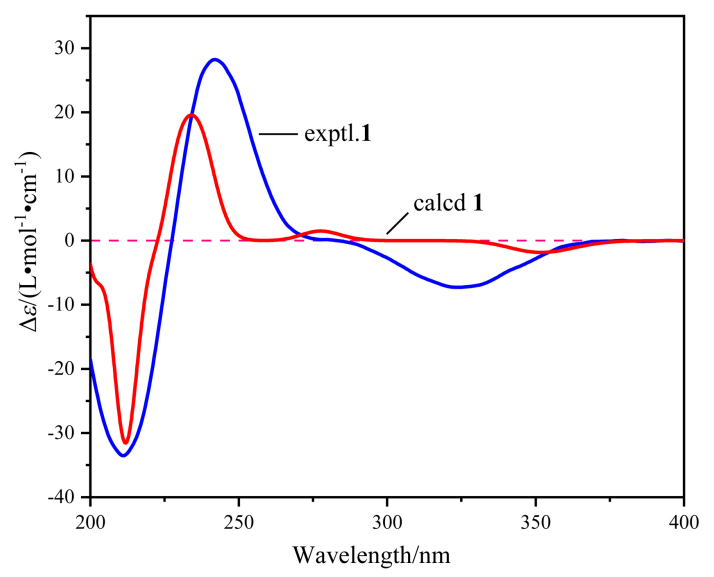

Figure 2 Experimental and calculated ECD spectra of compound $\mathbf{1}$
The molecular formula of casearoids $\mathrm{B}$ (2) was determined to be $\mathrm{C}_{20} \mathrm{H}_{30} \mathrm{O}_{3}$ by the (+)-HRESIMS ion peak at $m / z \quad 341.2096[\mathrm{M}+\mathrm{Na}]^{+}$(calcd 341.2087, $\mathrm{C}_{20} \mathrm{H}_{31} \mathrm{NaO}_{3}$ ) and ${ }^{13} \mathrm{C}$ NMR data. The IR absorptions at 3446, 1715 and $1668 \mathrm{~cm}^{-1}$ indicated the presence of hydroxy, carbonyl and olefin groups, respectively. With the aid of DEPT and HSQC experiments, its ${ }^{1} \mathrm{H}$ and ${ }^{13} \mathrm{C}$ NMR spectra (Table 1) indicated the presence of four methyls, seven methylenes (one oxygenated), two methines, three $\mathrm{sp}^{3}$ quaternary carbons, two carbonyl carbons $\left(\delta_{\mathrm{C}} 200.4\right.$ and 215.1$)$, and one trisubstituted double bond. Comparison of its NMR data with those of compound $\mathbf{1}$ (Table 1) revealed that they are structural analogs, and the major changes occurred at the A-ring. Two geminal methyls were attached at C-4 in the A ring of 2 replacing the 4,5-dimethyl substitution of the former by the HMBC correlation networks of $\mathrm{H}-1 / \mathrm{C}-2, \mathrm{C}-5$ and $\mathrm{C}-10 ; \mathrm{H}-3 / \mathrm{C}-1$ and $\mathrm{C}-2$; and $\mathrm{H}_{3}-20$ and $\mathrm{H}_{3}-19 / \mathrm{C}-3$, C-4 and $\mathrm{C}-5$. This was supported by the characteristic carbon resonances assignable for an $\alpha, \beta$-unsaturated ketone in the A ring (Table 1). Compound 2 shared $\mathrm{B}$ and $\mathrm{C}$ rings bearing the same appendages with 1 were verified by the coupling correlations of $\mathrm{H}-5 / \mathrm{H}-6 / \mathrm{H}-7 / \mathrm{H}-8 / \mathrm{H}-14$, and $\mathrm{H}-11 /$ $\mathrm{H}-12$ in the ${ }^{1} \mathrm{H}-{ }^{1} \mathrm{H}$ COSY spectrum, as well as the key HMBC correlations of $\mathrm{H}-8 / \mathrm{C}-13 ; \mathrm{H}_{3}-17 / \mathrm{C}-12, \mathrm{C}-13$ and C-14; $\mathrm{H}_{3}-18 / \mathrm{C}-8, \mathrm{C}-9, \mathrm{C}-10$ and $\mathrm{C}-11 ; \mathrm{H}_{2}-16 / \mathrm{C}-13$ and $\mathrm{C}-15$; and $\mathrm{H}_{3}-17 / \mathrm{C}-15$ (Figure $3 \mathrm{~A}$ ).

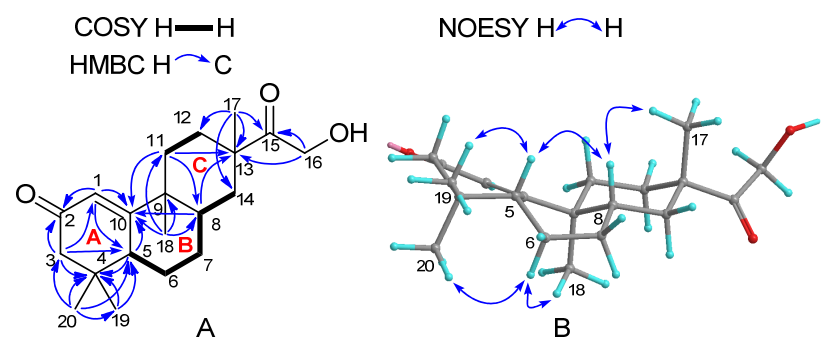

Figure 3 Key 2D NMR correlations of compound 2

The relative structure of compound $\mathbf{2}$ was elucidated by the NOESY analysis (Figure 3B), in which the NOESY correlations of $\mathrm{H}-5$ with $\mathrm{H}-8$, and $\mathrm{H}_{3}-19$, and $\mathrm{H}_{3}-17 / \mathrm{H}-8$ indicated that $\mathrm{H}-5, \mathrm{H}-8, \mathrm{Me}-17$ and $\mathrm{Me}-19$ were in the same side of the molecule, and were randomly assigned in a $\beta$-orientation. Consequently, the NOESY correlations of $\mathrm{H}-6 \alpha$ with $\mathrm{H}_{3}-20, \mathrm{H}_{3}-18$ indicated that these protons were $\alpha$-directed. The absolute configuration of $\mathbf{2}$ was determined as $5 R, 8 S, 9 S, 13 S$ by its compatible ECD curves between the experimental ECD spectrum and the calculated one (Figure 4).

Casearoids C (3) gave a molecular formula of $\mathrm{C}_{20} \mathrm{H}_{32} \mathrm{O}_{2}$ with five IHDs based on its HRESIMS and ${ }^{13} \mathrm{C}$ NMR data. Its 1D NMR data (Table 1) showed the existence of four methyls, four methylenes, four methines (two oxygenated), two quaternary carbons, and three double bonds (one monosubstituted, one disubstituted and one trisubstituted) in 3. These functional groups accounted for three IHDs, and the remaining two IHDs required compound $\mathbf{3}$ to be bicyclic. The planar structure of $\mathbf{3}$ was determined by the 


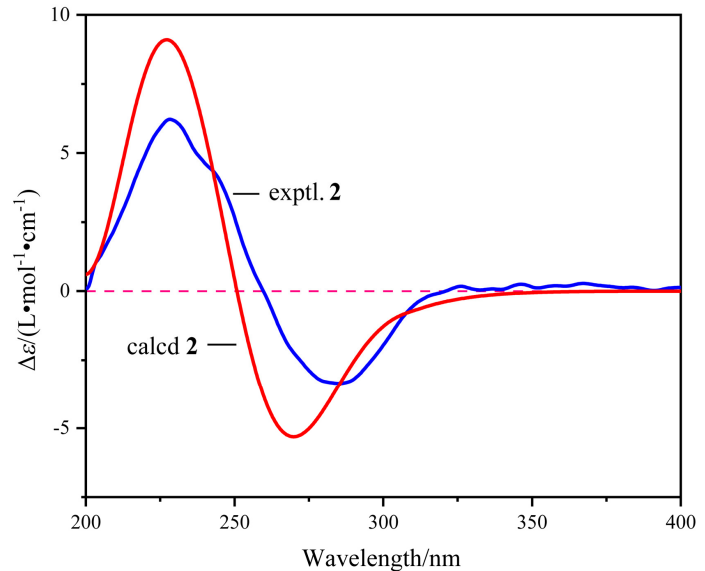

Figure 4 Experimental and calculated ECD spectra of compound 2

2D NMR analysis (Figure 5A), in which four spin systems (i, ii, iii and iiii) as depicted with bold bonds were identified by the ${ }^{1} \mathrm{H}-{ }^{1} \mathrm{H}$ COSY correlations. The HMBC correlations of $\mathrm{H}_{3}-18 / \mathrm{C}-1$, C-5 and C-10, and $\mathrm{H}_{3}-19(20) / \mathrm{C}-3$, C-4 and $\mathrm{C}-5$ forged $\mathrm{A}$ ring with a hydroxy group attached at $\mathrm{C}-3\left(\delta_{\mathrm{C}} 78.8\right)$. The HMBC correlations of $\mathrm{H}_{2}-6 / \mathrm{C}-8$ and C-10; H-7/C-8; $\mathrm{H}_{2}-17 / \mathrm{C}-7, \mathrm{C}-8$ and C-9; $\mathrm{H}_{3}-18 / \mathrm{C}-5$, C-9 and $\mathrm{C}-10$ furnished the $\mathrm{B}$ ring with the appendages of an exocyclic $\Delta^{8(17)}$ double bond and a hydroxy group at C-7 $\left(\delta_{\mathrm{C}} 73.8\right)$. Finally, a 3-methylpenta-1,3-diene motif was identified and attached to $\mathrm{C}-9$ based on the ${ }^{1} \mathrm{H}-{ }^{1} \mathrm{H}$ COSY correlations of $\mathrm{H}-9 / \mathrm{H}_{2}-11 / \mathrm{H}-12$ (fragment iii) and $\mathrm{H}-14 / \mathrm{H}-15$ (fragment iiii), as well as the HMBC correlations of $\mathrm{H}-14 / \mathrm{C}-12$, and $\mathrm{H}_{3}-16 / \mathrm{C}-12, \mathrm{C}-13$ and $\mathrm{C}-14$. Thus, compound 3 was determined to be a new labdane diterpeniod. ${ }^{[10]}$

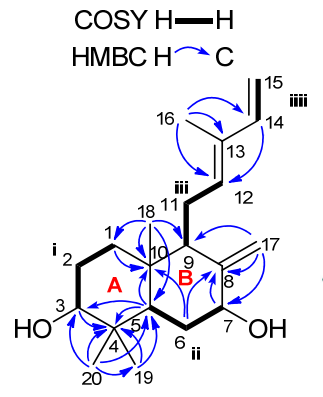

A

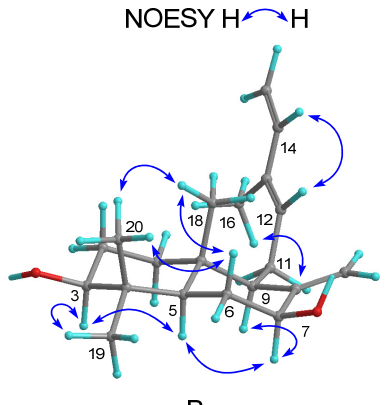

B
Figure 5 Key 2D NMR correlations of compound 3

The relative configuration of $\mathbf{3}$ was determined as shown by analysis of the NOESY data (Figure 5B). In details, the NOESY cross-peaks of $\mathrm{H}-3$ with $\mathrm{H}-5$ and $\mathrm{H}_{3}-19$; $\mathrm{H}-5$ with $\mathrm{H}-7$; and $\mathrm{H}-7$ with $\mathrm{H}-9$ revealed that these protons were cofacial and arbitrarily assigned as $\alpha$-oriented. The mutual NOESY correlations among $\mathrm{H}_{3}-18, \mathrm{H}_{3}-20$ and $\mathrm{H}-6 \beta$ then indicated that they were $\beta$-oriented. The $E$-geometry of the $\Delta^{12}$ double bond was assigned by the NOESY correlations of $\mathrm{H}_{2}-11 / \mathrm{H}_{3}-16$, and $\mathrm{H}-12 / \mathrm{H}-14$. The absolute configuration of 3 was determined as $3 S, 5 R, 7 S, 9 R, 10 S$ by the highly similarities between the experimental ECD and the calcu- lated ECD spectra (Figure 6).

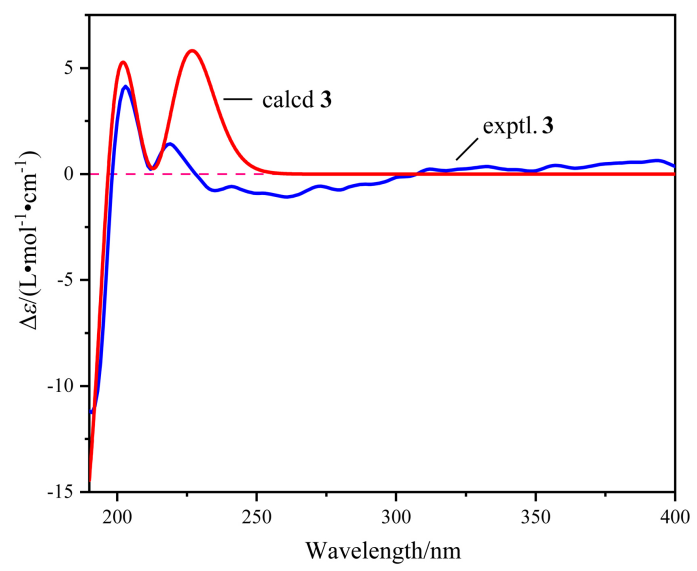

Figure 6 Experimental and calculated ECD spectra of compound 3

The molecular formula of casearoids D (4) was assigned as $\mathrm{C}_{20} \mathrm{H}_{30} \mathrm{O}_{3}$ with six IHDs by the $(+)$-HRESIMS ion peak at $\mathrm{m} / z \quad 341.2080[\mathrm{M}+\mathrm{Na}]^{+}$(calcd for $\mathrm{C}_{20} \mathrm{H}_{30} \mathrm{NaO}_{3}$, 341.2087 ) and the ${ }^{13} \mathrm{C}$ NMR data. With the assistance of DEPT and HSQC experiments, twenty carbon resonances (Table 1) were classified as four methyls, six methylenes, two methines (one oxygenated), one oxygenated tertiary carbon, three trisubstituted double bonds, and one carbonyl carbon $\left(\delta_{\mathrm{C}}\right.$ 174.4). The carbonyls and the double bonds accounted for four IHDs, and the remaining ones thus required the presence of two rings in compound 4. Detailed examination of the 2D NMR spectra constructed the 2D structure of 4. Analysis of the ${ }^{1} \mathrm{H}-{ }^{1} \mathrm{H}$ COSY spectrum revealed four structural units as depicted with bold bonds (Figure 7A), which were connected with the other functional elements to furnish the 14-membered macrocyclic framework by the HMBC correlations of $\mathrm{H}_{2}-2 / \mathrm{C}-1$ and $\mathrm{C}-14 ; \mathrm{H}_{2}-5 / \mathrm{C}-6$ and $\mathrm{C}-7$; H-11/H-12 and $\mathrm{H}-13 ; \mathrm{H}_{3}-18 / \mathrm{C}-3$, C-4 and C-5; and $\mathrm{H}_{3}-19 / \mathrm{C}-7, \mathrm{C}-8$ and C-9. Additionally, a hydroxyisopropyl group $\left(\delta_{\mathrm{C}-15} 74.2\right)^{[13]}$ was attached to $\mathrm{C}-1$ based on the HMBC correlations of $\mathrm{H}_{3}-16(17) / \mathrm{C}-1$ and $\mathrm{C}-15$. The remaining one IHD, as well as the key HMBC correlations from $\mathrm{H}-11$ and $\mathrm{H}_{2}-13$ to $\mathrm{C}-20\left(\delta_{\mathrm{C}} 174.4\right)$ indicated the existence of a $\alpha, \beta$-unsaturated $\gamma$-lactone between $\mathrm{C}-10$ and $\mathrm{C}-20$, which was supported by the C-10 chemical shift at $\delta_{\mathrm{C}} 80.0 .^{[15-17]}$ The 2D structure of 4 was thus delineated to be a cembrane analog.
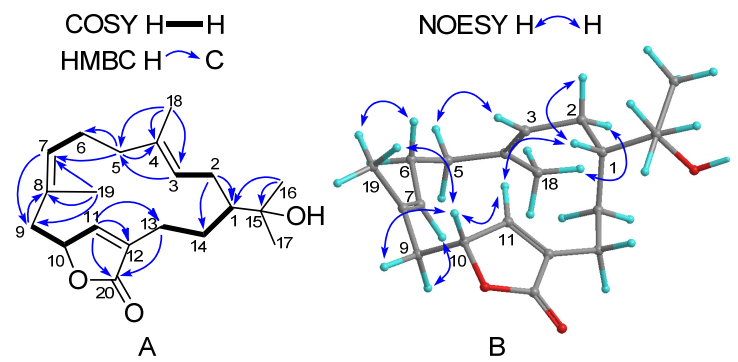

Figure 7 Key 2D NMR correlations of compound 4

The relative configuration of $\mathbf{4}$ was determined by the 
NOESY experiment (Figure 7B). The NOESY cross-peaks of $\mathrm{H}-10$ with $\mathrm{H}-9 \beta$ and $\mathrm{H}_{3}-19$, and $\mathrm{H}-11$ with $\mathrm{H}-1$ and $\mathrm{H}-10$, and $\mathrm{H}-1$ with $\mathrm{H}-2 \beta$ revealed that they were cofacial and arbitrarily assigned as $\beta$-oriented. As a consequence, the NOESY correlation of $\mathrm{H}-2 \alpha / \mathrm{H}_{3}-18$ permitted the Me-18 to be $\alpha$-oriented. The $E$-geometry for $\Delta^{3}$ and $\Delta^{7}$ double bonds were unambiguously assigned by the NOESY correlations of $\mathrm{H}-3 / \mathrm{H}_{2}-5$ and $\mathrm{H}-2 \alpha / \mathrm{H}_{3}-18$; and $\mathrm{H}-7 / \mathrm{H}-9 \alpha$ and $\mathrm{H}_{2}-6 / \mathrm{H}_{3}-19$, respectively. The absolute configuration of 4 was determined as $1 R, 10 R$ by the roughly matched experimental ECD spectrum and the calculated one (Figure 8). To further reinforce the structure of $\mathbf{4}$, calculations of ${ }^{13} \mathrm{C}$ NMR chemical shifts of $\mathbf{4}$ and its $1 R, 10 \mathrm{~S}$ isomer using Gauge-Independent Atomic Orbitals (GIAO) method were performed at B3LYP/6-31G(d,p) level. The results indicated that the $1 R, 10 R$ isomer showed higher correlation coefficient $\left(R^{2}, 0.99924\right)$ (Figure 9) and lower mean absolute deviation than those of the $1 R, 10 S$ isomer, which further confirmed the $1 R, 10 R$ configuration for 4 .

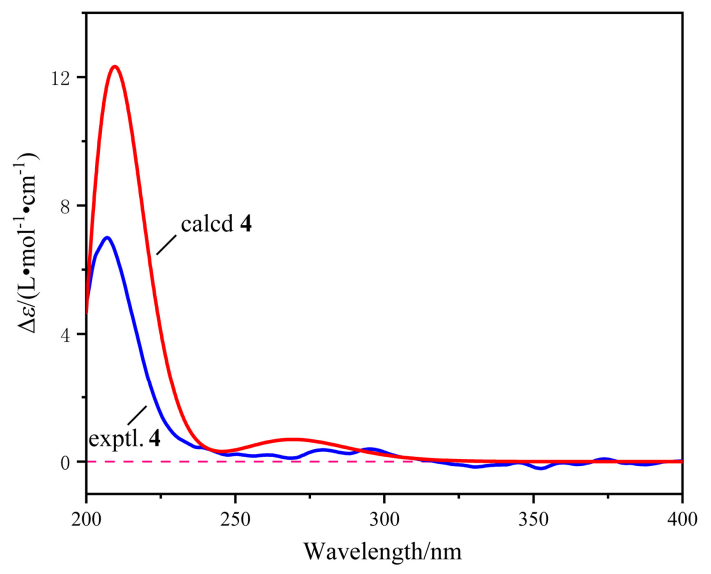

Figure 8 Experimental and calculated ECD spectra of compound 4

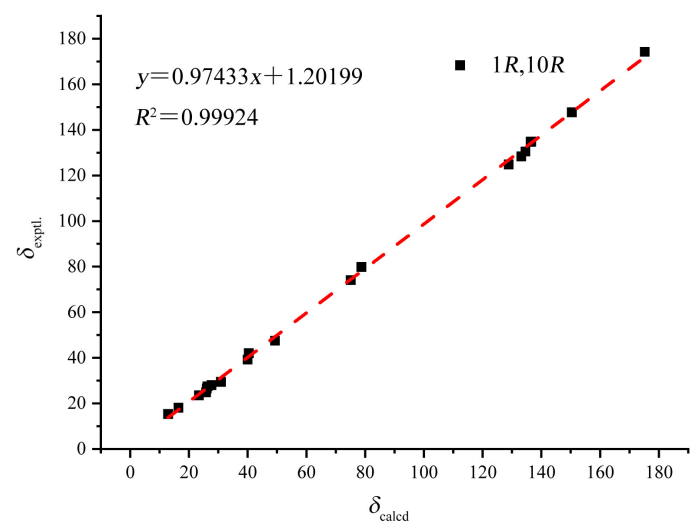

Figure 9 Experimental and calculated ${ }^{13} \mathrm{C}$ NMR chemical shifts of compound 4

\section{Conclusions}

Our preliminary chemical investigation on Microdesmis casearifolia led to the isolation and identification of four new diterpenoids casearoids $A \sim D(\mathbf{1} \sim \mathbf{4})$. Their structures with absolute configurations were elucidated by spectroscopic data analysis and ECD calculation. This study is a valuable collection for the diverse diterpenoids of natural products, and provides initial information on the chemical composition of the titled plant.

\section{Experimental section}

\subsection{Plant material}

The twigs of Microdesmis casearifolia were collected from Hainan Province, People's Republic of China. The plant sample was authenticated by Prof. Shi-Man Huang at Hainan University. A voucher specimen has been kept in our institute (accession number: Micas-2011-1Y).

\subsection{Extraction and isolation}

The dried sample powder $(10 \mathrm{~kg})$ was extracted at room temperature with $95 \%$ (volume fraction) $\mathrm{EtOH}$ for tree times to obtain the crude extract $(240 \mathrm{~g})$. The crude was then dissolved in $3 \mathrm{~L}$ of water to give a suspension, and partitioned with EtOAc. The EtOAc-soluble part $(65 \mathrm{~g})$ was chromatographed over D101-macroporous absorption resin, eluting with $50 \%, 80 \%$, and $95 \% \mathrm{EtOH}$ in $\mathrm{H}_{2} \mathrm{O}$ sequentially, to give fractions $\mathrm{F} 1 \sim \mathrm{F} 3$.

F2 (25 g) was separated on a column of MCI gel and eluted with gradients of $\mathrm{MeOH} / \mathrm{H}_{2} \mathrm{O}(30 \% \sim 100 \%$, volume fraction) to give five sub-fractions $\mathrm{F} 2 \mathrm{a} \sim \mathrm{F} 2 \mathrm{e}$. The F2a (3.3 g) containing mainly diterpenoids was separated on a silica gel column eluted with petroleum ether/acetone $(V$ : $V=20: 1$ to $1: 1)$ in gradient to yield fractions F2a1 F2a9. Fraction F2a2 (58 mg) was separated by semi-preparative high performance liquid chromatography (HPLC) (65\% acetonitrile in water as the mobile phase) to yield compounds 1 (3 mg), 2 (2 mg), 3 (2 mg) and 4 (2 mg).

Casearoids A (1): Yellow liquid. $[\alpha]_{\mathrm{D}}^{17.8}-11.0(c) 0.4$ in $\mathrm{MeOH})$; UV/Vis $(\mathrm{MeOH}) \lambda_{\max }\left[\log \varepsilon /\left(\mathrm{L} \cdot \mathrm{mol}^{-1} \cdot \mathrm{cm}^{-1}\right)\right]$ : 193 (3.56), 207 (3.45), 239 (3.85) nm; ECD (MeOH) $\lambda[\Delta \varepsilon /$

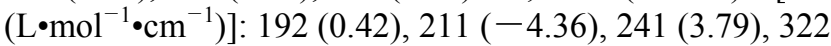
$(-0.95) \mathrm{nm}$; IR (KBr) $v_{\max }: 3451,2928,2858,1713,1663$, $1458,1378,1283,1261,736 \mathrm{~cm}^{-1} ;{ }^{1} \mathrm{H}$ NMR $\left(\mathrm{CDCl}_{3}\right)$ and ${ }^{13} \mathrm{C}$ NMR $\left(\mathrm{CDCl}_{3}\right)$ see Table $1 ;(+)$-ESIMS $\mathrm{m} / z: 341.5$ $[\mathrm{M}+\mathrm{Na}]^{+} ;(-)$-ESIMS $m / z \quad 317.6[\mathrm{M}-\mathrm{H}]^{-} ;(+)$ HRESIMS calcd for $\mathrm{C}_{20} \mathrm{H}_{31} \mathrm{O}_{3}[\mathrm{M}+\mathrm{H}]^{+} 319.2268$, found 319.2263 .

Casearoids B (2): Yellow liquid. $[\alpha]_{\mathrm{D}}^{17.7}-10.0\left(\begin{array}{ccc}c & 0.07\end{array}\right.$ in $\mathrm{MeOH})$; UV/Vis $(\mathrm{MeOH}) \lambda_{\max }\left[\log \varepsilon /\left(\mathrm{L} \cdot \mathrm{mol}^{-1} \cdot \mathrm{cm}^{-1}\right)\right]$ : 195 (3.60), 239 (3.30) nm; ECD $(\mathrm{MeOH}) \lambda\left[\Delta \varepsilon /\left({\mathrm{L} \cdot \mathrm{mol}^{-1}}^{-1}\right.\right.$ $\left.\mathrm{cm}^{-1}\right)$ ]: 192 (1.57), $228(0.80), 289(-0.41) \mathrm{nm}$; IR (KBr) $v_{\max }: 3446,2926,2854,1715,1668,1456,1374,1260$, 1098, 1029, $802 \mathrm{~cm}^{-1} ;{ }^{1} \mathrm{H}$ NMR $\left(\mathrm{CDCl}_{3}\right)$ and ${ }^{13} \mathrm{C}$ NMR $\left(\mathrm{CDCl}_{3}\right)$, see Table 1; (+)-ESIMS $m / z: 341.3[\mathrm{M}+\mathrm{Na}]^{+}$; $(+)$-HRESIMS calcd for $\mathrm{C}_{20} \mathrm{H}_{31} \mathrm{NaO}_{3}[\mathrm{M}+\mathrm{Na}]^{+}$ 341.2087, found 341.2096.

Casearoids C (3): Yellow liquid. $[\alpha]_{\mathrm{D}}^{17.7}-4.5(c 0.20$ in $\mathrm{MeOH}) ; \mathrm{UV} / \mathrm{Vis}(\mathrm{MeOH}) \lambda_{\max }\left[\log \varepsilon /\left(\mathrm{L} \cdot \mathrm{mol}^{-1} \bullet \mathrm{cm}^{-1}\right)\right]$ : 195 (3.76), 229 (3.39) nm; ECD $(\mathrm{MeOH}) \lambda\left[\Delta \varepsilon /\left(\mathrm{L} \bullet \mathrm{mol}^{-1} \bullet\right.\right.$ $\left.\mathrm{cm}^{-1}\right)$ ]: 192 (-1.74), 194(0.13), 197(0.58), 205 (0.19), 
$225(-0.13) \mathrm{nm}$; IR (KBr) $v_{\max }: 3391,2923,2852,1716$, $1668,1456,1261,1089,1025 \mathrm{~cm}^{-1} ;{ }^{1} \mathrm{H}$ NMR $\left(\mathrm{CDCl}_{3}\right)$ and

${ }^{13} \mathrm{C}$ NMR $\left(\mathrm{CDCl}_{3}\right)$ see Table 1; (-)-ESIMS m/z 303.2 $[\mathrm{M}-\mathrm{H}]^{-} ;(+)$-HRESIMS calcd for $\mathrm{C}_{20} \mathrm{H}_{32} \mathrm{NaO}_{2}[\mathrm{M}+$ $\mathrm{Na}]^{+}$327.2295, found 327.2295.

Casearoids D (4): Yellow liquid. $[\alpha]_{\mathrm{D}}^{17.9}-21.0$ (c 0.1 in $\mathrm{MeOH})$; UV/Vis $(\mathrm{MeOH}) \lambda_{\max }\left[\log \varepsilon /\left(\mathrm{L} \cdot \mathrm{mol}^{-1} \cdot \mathrm{cm}^{-1}\right)\right]$ :

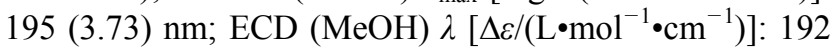
(2.76), 194 (0.23), 207 (1.24) nm; IR (KBr) $v_{\max }$ : 3421, 2924, 2853, 1738, 1574, 1436, 1379, 1260, 1170, 1094, $1031,804 \mathrm{~cm}^{-1} ;{ }^{1} \mathrm{H}$ NMR $\left(\mathrm{CDCl}_{3}\right)$ and ${ }^{13} \mathrm{C} \mathrm{NMR}\left(\mathrm{CDCl}_{3}\right)$, see Table 1; (+)-ESIMS $m / z: 341.4[\mathrm{M}+\mathrm{Na}]^{+} ;(-)$ESIMS $m / z$ : $317.8[\mathrm{M}-\mathrm{H}]^{-}$; (+)-HRESIMS calcd for $\mathrm{C}_{20} \mathrm{H}_{30} \mathrm{NaO}_{3}[\mathrm{M}+\mathrm{Na}]^{+}$341.2087, found 341.2080.

\section{$4.3{ }^{13} \mathrm{C}$ NMR calculations}

${ }^{13} \mathrm{C}$ NMR chemical shifts calculations at B3LYP/6-31G $(\mathrm{d}, \mathrm{p})$ level based on the gauge independent atomic orbital (GIAO) and in solvent of chloroform (CPCM).

\subsection{ECD calculations}

The ChemDraw_Pro_15.0 software with an MM2 force field was used to establish the initial conformations of the target molecules. Conformational searches using mixed torsional/Low-mode sampling method with MMFFs force field in an energy window of $8.37 \mathrm{~kJ} / \mathrm{mol}$ were carried out by means of the conformational search module in the Maestro 10.2 software (Maestro Technologies, Inc., Trenton, NJ, USA). The re-optimization and the following TDDFT calculations of the re-optimized conformations were all performed with the Gaussian 09 software (Gaussian, Inc., Wallingford, CT, USA ${ }^{[18]}$ at the B3LYP/6-311G $(d, p)$ level, in vacuo. Frequency analysis was performed as well to confirm that the re-optimized conformers were at the energy minima. Finally, the SpecDis 1.64 software (https://specdis-software.jimdo.com/) ${ }^{[19]}$ was used to obtain the Boltzmann-averaged ECD spectra.

Supporting Information General experimental procedures and chiral analysis, and 1D and 2D NMR, MS, and IR spectra of compounds $1 \sim \mathbf{4}$. The Supporting Information is available free of charge via the Internet at http://sioc-journal.cn.

\section{References}

[1] Li, P. T.; Zhang, Y. T., In Flora of China, Vol. 43, Eds.: Xu, L. R.;
Huang, C. J., Science Press, Beijing, 1998, p. 2.

[2] Zamble, A.; Sahpaz, S.; Hennebelle, T.; Carato, P.; Bailleul, F. Chem. Biodiversity 2006, 3, 982.

[3] Zamble, A.; Sahpaz, S.; Brunet, C.; Bailleul, F. Phytomedicine 2008, $15,625$.

[4] Roumy, V.; Hennebelle, T.; Zamble, A.; Yao, J. D.; Sahpaz, S.; Bailleul, F. Eur. J. Mass Spectrom. 2008, 14, 111.

[5] Zamble, A.; Martin-Nizard, F.; Sahpaz, S.; Reynaert, M.-L.; Staels, B.; Bordet, R.; Duriez, P.; Gressier, B.; Bailleul, F. Phytother. Res. 2009, 23, 892.

[6] Zamble, A.; Hennebelle, T.; Sahpaz, S.; Bailleul, F. Chem. Pharm. Bull. 2007, 55, 643.

[7] Akpanyung, E. O.; Ita, S. O.; Opara, K. A.; Davies, K. G.; Ndem, J. I.; Uwah, A. F. J. Med. Plants Res. 2013, 7, 2338.

[8] Ni, S.-J.; Li, J.; Li, M.-Y. Chem. Biodiversity 2018, $15,1$.

[9] Yang, Y.; Zhang, Y.; Liu, D.; Min, L.; Weber; Shao, B.; Lin, W.-H. Fitoterapia 2015, 103, 277.

[10] Bohlmann, F.; Knoll, K. H.; King, R. M.; Robinson, H. Phytochemistry 1979, 18, 1997.

[11] Ansell, S. M.; Pegel, K. H.; Taylor, D. A. H. Phytochemistry 1993, 32,953 .

[12] Jia, R.; Shi, Y.-H.; He, P.-M.; Guo, Y.-W. Chin. J. Nat. Med. 2010, $8,422$.

[13] Duh, C.-Y.; Wang, S.-K.; Weng, Y.-L.; Chiang, M.-Y.; Dai, C.-F. J. Nat. Prod. 1999, 62, 1518.

[14] Kijjoa, A.; Polonia, M. A.; Pinto, M. M. M.; Kitiratakarn, T.; Gedris, T.; Herz, W. Phytochemistry 1994, 37, 197.

[15] Mulholland, D. A.; Langat, M. K.; Crouch, N. R.; Coley, H. M.; Mutambi, E. M.; Nuzillard, J. M. Phytochemistry 2010, 71, 1381.

[16] Langat, M. K.; Crouch, N. R.; Smith, P. J.; Mulholland, D. A. J. Nat. Prod. 2011, 74, 2349.

[17] Kawakami, S.; Matsunami, K.; Otsuka, H.; Lhieochaiphant, D.; Lhieochaiphant, S. J. Nat. Med. 2013, 67, 410.

[18] Frisch, M. J.; Trucks, G. W.; Schlegel, H. B.; Scuseria, G. E.; Robb, M .A.; Cheeseman, J. R.; Scalmani, G.; Barone, V.; Mennucci, B.; Petersson, G. A.; Nakatsuji, H.; Caricato, M.; Li, X.; Hratchian, H. P.; Izmaylov, A. F.; Bloino, J.; Zheng, G.; Sonnenberg, J. L.; Hada, M.; Ehara, M.; Toyota, K.; Fukuda, R.; Hasegawa, J.; Ishida, M.; Nakajima, T.; Honda, Y.; Kitao, O.; Nakai, H.; Vreven, T.; Montgomery, Jr., J. A.; Peralta, J. E.; Ogliaro, F.; Bearpark, M.; Heyd, J. J.; Brothers, E.; Kudin, K. N.; Staroverov, V. N.; Kobayashi, R.; Normand, J.; Raghavachari, K.; Rendell, A.; Burant, J. C.; Iyengar, S. S.; Tomasi, J.; Cossi, M.; Rega, N.; Millam, J. M.; Klene, M.; Knox, J. E.; Cross, J. B.; Bakken, V.; Adamo, C.; Jaramillo, J.; Gomperts, R. E.; Stratmann, O.; Yazyev, A. J.; Austin, R.; Cammi, C.; Pomelli, J. W.; Ochterski, R.; Martin, R. L.; Morokuma, K.; Zakrzewski, V. G.; Voth, G. A.; Salvador, P.; Dannenberg, J. J.; Dapprich, S.; Daniels, A. D.; Farkas, O.; Foresman, J. B.; Ortiz, J. V.; Cioslowski, J.; Fox, D. J., Gaussian 09, Rev. B.01, 2010, Gaussian Inc., Wallingford CT.

[19] Bruhn, T.; Schaumloeffel, A.; Hemberger, Y.; Bringmann, G. Chirality 2013, 25, 243. 